DOROTA OKRASIŃSKA

Fundacja Gotowi na Zmiany, Kraków, Polska - Foundation Ready for Changes, Kraków, Poland

\title{
Kontinuum wartości pedagogicznych - metody i narzędzia na przykładzie modelu greckiego w warunkach zmienności - analiza kognitywna
}

\section{Continuum of pedagogical values - methods and tools based on the example of the Greek model under variation conditions - cognitive analysis}

Streszczenie: Celem niniejszego artykułu jest wskazanie możliwości kształtowania młodego pokolenia przez kontynuację ponadczasowych postaw pedagogicznych w świetle aktualnego kryzysu gospodarczego. Przedmiotem analizy jest sprecyzowanie i dostosowanie dostępnych metod oraz narzędzi współczesnego pedagoga w myśl greckich systemów filozoficzno-etycznych względem towarzyszących ograniczeń i zmienności. Jako empiryczną metodę badań nad problematyką przedstawionych zagadnień wybrano analizę kognitywną. Analiza ta zyskuje na znaczeniu w kontekście aktualnych problemów gospodarczych oraz transformacji globalnych wywołanych pandemią, a tym samym zmianą mechanizmów nauczania na hybrydowy i zdalny. W niniejszym rozważaniach skoncentrowano się na roli wartości pedagogicznych na podstawie założeń greckich filozofów jako prekursorów myśli pedagogicznej w celu zdiagnozowania aktualnych potrzeb oraz czerpania inspiracji z ich dorobku metodycznego. W wyniku analizy wskazano metody i narzędzia pracy z uczniem nad komunikacją, indywidualnością i doświadczaniem przez inicjowanie społecznych kontaktów z kulturą oraz językiem. Nadano także znaczenie relacji między nauczycielem a uczniem, opartej na partnerstwie i empatii, co daje wymierne korzyści w procesie kształtowania jednostki i chroni ją przed wykluczeniem.

Abstract: The aim of this article is to indicate the possibility of shaping the young generation by contin-
uing the timeless pedagogical attitudes in the light of the current economic crisis. The subject of the anal-
ysis is to specify and adjust the available methods and tools of a modern pedagogue according to Greek
philosophical and ethical systems in relation to the accompanying limitations and variability. A form of
cognitive analysis has been chosen as an empirical method of research into the issues presented. This
analysis becomes increasingly important in the context of current economic issues and global trans-
formations caused by pandemics, and thus the change in learning mechanisms to hybrid and remote
learning. Thus, this consideration focuses on the role of pedagogical values based on the assumptions of
Greek philosophers as precursors of pedagogical thought in order to diagnose current needs and draw 
inspiration from their methodological achievements. As a result of the analysis, methods and tools for working with students on communication, individuality and experience by initiating social contacts with culture and language were identified. The importance of the relationship between teacher and student, based on partnership and empathy, was also given, which gives tangible benefits in the process of shaping the individual, protecting him/her from exclusion.

Słowa kluczowe: edukacja; heurystyka; kryzys, model grecki; wartości pedagogiczne

Keywords: crisis; education; heuristics; pedagogical values; the Greek model

Otrzymano: 11 lutego 2021

Received: 11 February 2021

Zaakceptowano: 25 maja 2021

Accepted: 25 May 2021

Sugerowana cytacja/Suggested citation:

Okrasińska, D. (2021). Kontinuum wartości pedagogicznych - metody i narzędzia na przykładzie modelu greckiego w warunkach zmienności - analiza kognitywna. Przedsiębiorczość - Edukacja [Entrepreneurship - Education], 17(1), 115-125. https://doi.org/10.24917/20833296.171.9

\section{Wstęp}

Niniejszy artykuł jest próbą określenia metod i narzędzi wraz z wartościami, które mogą wpłynąć na proces kształtowania młodego pokolenia w obliczu narastającego kryzysu gospodarczego. Metodyka pracy, narzędzia i indywidualna postawa pedagoga wydają się być kluczowe w sytuacji odwrócenia się społeczeństwa od wielowiekowych wartości, wzorców oraz tradycji. W procesie wychowania ważnym punktem odniesienia staje się zwrócenie do indywidualności ucznia oraz zaakceptowanie jego autonomii.

Ocena niniejszej sytuacji wraz ze zbiorem rozważań została ujęta w formie analizy kognitywnej, co zwraca uwagę na aspekt poznawczy artykułu oraz interdyscyplinarność problemu. Kogniwistyka jako nauka opiera się na obserwacji i analizie, które stanowią narzędzia do badań empirycznych (Thagard, 2014; Zalta, 2017). Opracowanie ma ponadto charakter studiów literaturowych opartych na danych wtórnych. Posłużono się w nim następującą metodą badawczą celem uaktualnienia przyjętych założeń: oryginalne idee greckich filozofów na przełomie ostatniej dekady stały się inspiracją, na przykładzie której nowoczesna literatura odnajduje aktualne przesłanie, nadając nowe znaczenie poznanym tezom. Dane wtórne, które wykorzystano, odwołują się do znanych mistrzów greckich, m.in. Hezjoda czy Sokratesa, których dorobek poddano wielopłaszczyznowej interpretacji oraz wznowieniu. Tym samym poddano analizie elementy kulturowe $\mathrm{w}$ zestawieniu $\mathrm{z}$ tłumaczeniami, co daje szerszy obraz wiedzy z czasów antycznych (Zalewska-Jura, 2021).

Dla niniejszej analizy istotną wartość mają kluczowe punkty odniesienia na przestrzeni literackiego dorobku Greków. W literaturze dokonano klasyfikacji literatury greckiej na przełomie V-VI w. p.n.e. na szkołę soficką, sokratejską oraz platońską. Ich wspólnym punktem było traktowanie edukacji jako przywileju, a jednocześnie okazji do samopoznania oraz ukształtowania indywidualnej tożsamości (Giovanni, 2000).

Warto wskazać ważne punkty w kulturze hellenistycznej, które wyszczególniono w analizie. Jednym z nich było wyodrębnienie ideału piękna i dobroci - tzw. kalokagathia - co stanowiło archetyp pojęcia arystokratycznego ideału człowieka jako istoty wszechstronnej (Litak, 2010). Wzorzec ten oparto na komplementarności zainteresowań 
- poezja, sztuka, muzyka, co zestawiono z rozeznaniem w świecie polityki, bogatą retoryką oraz posłuszeństwem bogom i kultem ciała.

Kolejnym kluczowym wzorcem istotnym w aspekcie pedagogiki jest ideał etyczny areté, a więc określenie natury człowieka, co często w literaturze błędnie utożsamiane jest z cnotą. Narzędziami do określenia jego natury są wiedza i poznanie. Zatem człowiek nabywa cnotę wraz z samopoznaniem areté (Giovanni, 2000: 326).

Wymienione wzorce oddawały istotę głównego założenia greckiej edukacji, w myśl którego najważniejszym zadaniem pedagoga jest pielęgnowanie duszy ucznia. Tym samym następuje poznanie oparte na prawdzie, naturze człowieka, cnocie i autonomii, co stanowi warunki do nabycia wiedzy.

Niniejszy artykuł jest próbą odpowiedzi na pytanie: jakie postawy pedagogiczne z perspektywy metod i wartości - warto kontynuować w nawiązaniu do modelu greckiego w warunkach kryzysu i zmienności. Nasuwają się tym samym pytania pomocnicze do dalszej eksploracji badawczej, zwracające uwagę na możliwości czerpania z dorobku Greków: Które z wybranych założeń mają szansę na przeniesienie do aktualnej sytuacji gospodarczej? Jakimi priorytetami warto się kierować zgodnie z wybranymi rozwiązaniami? Na podstawie tych pytań zwrócono uwagę na potrzeby ucznia oraz narzędzia pracy nauczyciela korzystającego z idei greckich filozofów. Metody te usytuowano także w systemie współczesnej edukacji ze wskazaniem na jej potrzeby i możliwości.

\section{Refleksje mistrzów nad samodzielnym doświadczaniem}

Dziedzictwo Sokratesa ukształtowało początki pedagogiki wychowania, której korzenie stanowią nauki filozoficzne kontynuatorów idei sokratejskich. Sokrates w swojej filozofii wyznaczył etyczne filary człowieczeństwa będące konstruktem dla nauk o wychowaniu. Cyceron zwrócił uwagę na poglądy mistrza, wskazując, że jako pierwszy zwrócił on swoją filozofię w stronę rodziny wraz z kwestią obyczajowości, a tym samym rozróżnienia dobra i zła (Śmigaj, 2010: 4-10). Przyjął on wartości istotne dla życia zgodnego z umiejętnościami sklasyfikowanymi przez niego do sfery rozumu: dysponowanie samym sobą (enkrateia), wolność (eleutheria) i samowystarczalność (autarkia) (Łażewska, 2011: 36). Funkcje te miały zagwarantować etyczne postrzeganie świata przez jednostkę i jej samodzielność. W myśl tego założenia możliwość samostanowienia o sobie i zaradność stanowią fundament procesu kształcenia. Sokrates zwrócił także uwagę na ideę samej duszy, zaznaczając, że „człowiekiem jest jego dusza” (Giovanni, 2000: 316). Stanowi ona element jego „świadomego ja, jest intelektualną i moralną osobowością” (Giovanni, 2000: 317). Podobne spostrzeżenia opisywał uczeń Sokratesa, Platon, w Liście VII napisanym do Syrakuza Dionizosa, którego edukował. Platon wskazywał w nim na nadrzędną rolę duszy w drodze do wiedzy i rozumienia (Dembiński, 2000: 96). Tym samym pogłębiało to ideę sokratejską, zwracającą uwagę na tożsamość dziecka jako jednostki, co daje początek rozwijania jej w obliczu możliwości do intelektualnego rozwoju. Z syntezy tych założeń wynika, że można wydobywać potencjał z dziecka jako istoty autonomicznej głównie w warunkach sprzyjających pogłębianiu świadomości człowieka oraz w poszanowaniu jego suwerenności. Czy zatem sytuacje kryzysowe na przestrzeni dziejów, takie jak głód, wojna, kryzys gospodarczy bądź pandemia i zachwianie gospodarką światową, nie stanowią zagrożenia dla możliwości rozwoju dziecka w kontekście ograniczenia swobód i kontaktów międzyludzkich? 
Istotnym komponentem niniejszej analizy jest wskazanie nowej perspektywy postrzegania nauki i wychowania w opozycji do systemowego i strukturalnego modelu współczesnej edukacji, opartego na programach oraz wynikach. Warto tutaj wskazać przykład szkoły platońskiej, której założenia skoncentrowane były na idei pojmowania nauki jako wspólnego dobra. Uczniowie natomiast uznawani byli za braci odpowiedzialnych za zbiorowość, a proces edukacji traktowano jako przywilej i sekret dostępny tylko dla adeptów, co dodatkowo podnosiło rangę nauki. Edukację opierano także na budowaniu cnoty i erudycji (Jacko, 2017). Współczesna szkoła oddala się od idei prestiżu czy wspólnoty na rzecz struktury zdominowanej przez liczebność klas i nadmiar programu, co nie pozostawia wiele miejsca na pielęgnowanie jakości. W sytuacji ograniczenia nauki stacjonarnej jakość edukacji, a wraz z nią stymulacja ucznia, relacja z nim, jak i analiza jego potrzeb wydają się być utrudnione. Konieczność nauki zdalnej wymusza tym samym obowiązek korzystania z komputerów, co wyklucza poczucie jednostki jako członka zbiorowości wspólnej idei, a w następstwie sprowadza rolę nauki do zautomatyzowanej czynności i obowiązku.

Podobne postulaty wyrażał Arystoteles w swojej teorii państwa, która zakłada, że człowiek z natury jest stworzony do życia w społeczeństwie (Łażewska, 2011: 60), natomiast wychowanie jest formą sztuki narodu (Wasilewski, 2017: 168). Zgodnie z tym założeniem, tylko ten konstrukt umożliwia ukształtowanie człowieka wraz z jego cnotami. Warto dodać, że Arystoteles każdy byt określa mianem „substancji”, której podporządkowane są pewne cechy - „przypadłości”, co podkreśla znaczenie roli indywidualizmu ucznia (Wasilewski, 2017). Siła woli stanowiła według niego podstawowy przymiot w zarządzaniu swoimi potrzebami czy też słabościami (Szyrwińska-Hörig, 2021). Tym samym uznawał on twórczą naturę człowieka za moc kreacji, która jest w stanie wznieść się ponad dorobek tradycji (Kwietniewska, 2020). W świetle współczesnej edukacji aspekty dostrzeżenia autonomii w jednostce wraz z jednoczesnym zapewnieniem jej rozwoju w strukturze społeczeństwa stanowią podstawowy składnik kompetencji pedagoga.

Trzeba tu z całą stanowczością powiedzieć, że zjawisko kryzysu gospodarczego, a więc brak równowagi pomiędzy globalną podażą a popytem, znacząco redefiniuje obraz współczesnej edukacji (Marek, Szymańska-Wieczorek, 2011: 228). Sam Arystoteles zaznaczał w teorii państwa, że najbardziej znaczącą warstwą w społeczeństwie jest klasa średnia. W sytuacji wyhamowania gospodarczego, kiedy poszczególne branże są pośrednio „zamrażane”, następuje lawinowy wzrost bezrobocia oraz pomniejszanie sektorów małych i średnich przedsiębiorstw. Prowadzi to do izolacji społeczeństwa oraz przerw względem wymiany wiedzy i doświadczeń pomiędzy strukturami. Zważywszy na fakt, że kryzysy współczesne przyjmują na ogół wymiar globalny, do problemu edukowania społeczeństwa jako wrażliwej tkanki zbiorowości należy podchodzić ze stoickim wyważeniem i umiejętnym doborem narzędzi dydaktycznych (Marek, Szymańska-Wieczorek, 2011: 234). Troska o autonomię jednostki z jednoczesnym zapewnieniem jej warunków rozwojowych i bytowych szczególnie zyskuje tu na znaczeniu w kontekście poglądów Pitagorasa, który podkreślał wielką rolę uszlachetniania duszy przez poezję czy muzykę (Jodłowska, 2016: 88). Dochodzimy tu zatem do znaczenia kultury w zakresie kształtowania tożsamości ucznia. Szukanie prawdy oraz zapewnienie indywidualizacji nauczania było kontynuacją jego założeń. Zgodnie z tym, umożliwienie uczniowi ćwiczenia nabytych umiejętności w praktyce stanowiło podstawowe kluczowe zadanie pedagoga (Wasilewski, 2017: 226). Tak przyjęty paradygmat konstruktywistyczny zakładał indywidualne 
poznanie oraz naukę poprzez suwerenne doświadczenie. Tym samym praktyczne przeżycie ma odniesienie w kontekście jednostki, co podnosi rangę pedagoga do roli mentora, który swoje działania metodyczne w myśl idei greckich powinien opierać na wyznaczeniu suwerennej ścieżki dydaktycznej każdemu uczniowi.

\section{Moralność i wielokulturowość a kryzys}

Istotnymi komponentami edukacji greckiej były wartości moralne, które należało pielęgnować w trosce o kształtowanie cnoty i dobrego wychowania młodego pokolenia. Grecy są prekursorami tzw. filozofii moralnej, będącej zbiorem powszechnych ustaleń i zależności dla ludzi. Równie istotna była wiara w opatrzność oraz sprawiedliwość w kontekście owej moralności (Teodorovich, 2021). Ta refleksja etyczna miała już swoje początki w dziełach Homera - Iliadzie i Odysei (Giovanni, 2000). Fundamentalne dla wartości pedagogicznych cechy, takie jak bohaterstwo Achillesa czy też postawa Penelopy, którą można uznać za archetyp lojalności i wierności, stanowią wzór wychowawczy dla młodego pokolenia. Szerszą perspektywę w aspekcie moralności zaproponował Hezjod, propagujący życie wiejskie, zgodne $\mathrm{z}$ naturą, religijność oraz kult pracy. Zagadnienia te rozwinął on w swoim dziele etyczno-dydaktycznym pt. Prace i dnie (Giovanni, 2000: 225), które zachęcało do umiarkowania, życzliwości i cnoty, co nadawało znaczenie edukacji Hellenów. Wątek moralności podejmowany był także przez sofistów, tzw. wędrownych nauczycieli, którzy uznawali cnotę za fundament wiedzy.

Wskazane w opracowaniu myśli natury etycznej w świetle współczesności prowadzą do wniosków, których transformację należy podkreślić w skali makrospołecznej. L. Zarzycki w Teoretycznych podstawach wychowania dokonał klasyfikacji czynników mających wpływ na przeformułowanie znaczenia wartości moralnych. Zaproponował on ujęcie krytyczne dla przyjętej rzeczywistości, w którym zwrócił uwagę na rozwój „dzikiego kapitalizmu” w Polsce oraz „prawo dżungli” po upadku państwa socjalistycznego, co może implikować oszustwa gospodarcze, walkę o wpływy, a tym samym przekładać się na indywidualną sytuację rodzin oraz wychowanie (Zarzycki, 2012: 119). Kryzys materialny związany jest nieuchronnie z kryzysem moralnym, co prowadzi pedagoga na płaszczyznę wychowawczą w obliczu potrzeb dzieci. Braki materialne i etyczne młodego pokolenia w kontekście rzeczywistości opartej na kulcie władzy wymagają podejścia bardziej empatycznego i zindywidualizowanego niż dotychczas. Kompetencje pedagoga w tym ujęciu katalizują tym samym rozwój umiejętności miękkich.

Kolejne znaczenie warto nadać kwestii wielojęzyczności oraz wielokulturowości. Przemiany systemowe wraz z uzyskaniem członkostwa Polski w Unii Europejskiej przyspieszyły procesy migracyjne, co upowszechniło w społeczeństwie naukę języków obcych (Czekańska-Mirek, 2016: 1). Za czasów Imperium Rzymskiego nauka języków koncentrowała się na triadzie: rzymski, grecki oraz łacina. Język wówczas stał się także implikacją kultury oraz stanowił gwarancję jej dziedzictwa. Jeden z czołowych greckich mówców, uczeń Sokratesa - Izokrates - stał się twórcą szkoły ukierunkowanej na kulturę języka. Tak narodziła się retoryka wraz z krytycznym postrzeganiem jakości wypowiedzi (Gaj, 2020). Izokrates wyodrębnił język prozy od języka poezji, przykładał też ogromną wagę do wartości wymowy. Zwrócił również uwagę na kwestię wiarygodności wizerunku oraz przekazu werbalnego, który powinien być oparty na przyzwoitości etycznej, zasadach dobroci i piękna (Danek, 2020). Na przestrzeni wieków nauka ta zyskała na znaczeniu 
także w aspekcie tożsamości narodowej, którą w przestrzeni edukacji kształtowano równolegle z pielęgnowaniem języka i patriotyzmem. Tak wielopłaszczyznowe wychowanie patriotyczne przejawia się dzisiaj przez inicjatywy pedagoga w postaci omawianych czy świętowanych rocznic, pielęgnowaniu flagi narodowej oraz dziedzictw kultury w formie wycieczek edukacyjno-kulturowych (Zarzycki, 2012: 127). Inspirującą ideą może być także organizacja spotkań z kombatantami, co nadaje wychowaniu patriotycznemu wymiar moralny.

\section{Rola indywidualizacji ucznia}

Istotnym aspektem w rozwoju samodzielności oraz przedsiębiorczości uczniów jest stwarzanie nowych ścieżek nauczania opartych na pitagorejskim doświadczaniu oraz nurcie konstruktywistycznym. Na Litwie wyróżnia się szkoła Romuvos w Szawlach, gdzie uczniowie klas V-VIII sami wybierają moduły kształcenia, prowadząc jednocześnie teczki indywidualnej ścieżki edukacyjno-zawodowej oraz współdecydując o swoim rozwoju (Chrzanowska, Szumski, 2019: 35).

Podobna inicjatywa występuje w Polsce w wielu autorskich szkołach o tzw. alternatywnym profilu edukacji. Przykładem może być ALA, czyli wrocławskie Autorskie Liceum Artystyczne, które funkcjonuje jako eksperymentalna szkoła skoncentrowane na indywidualnym rozwoju ucznia. Zgodnie z założeniami dyrektora metodycznego, Mariusza Budzyńskiego, uczniowie mają tutaj możliwość wyboru wychowawcy i tutora, szkoła nie stosuje tradycyjnych dzwonków ani ocen niedostatecznych, natomiast wychowankowie sami kreują własny zindywidualizowany tok nauczania (Budzyński, 2021). ALA umożliwia także uczniom kształcenie w zakresie przedmiotów artystycznych. W takim układzie nauczyciel wchodzi w rolę eksperta, który wspiera ucznia w jego planach, pełniąc podobną funkcję do mistrza greckiego jako niezależnego facylitatora i mentora.

Współczesne szkoły eksperymentalne i alternatywne nawiązują do kultury humanistycznej zapoczątkowanej przez sofistów w V w. p.n.e. Jak pisze R. Giovanni, nauczano wówczas retoryki, sztuki, wychowania, polityki, języka oraz etyki (Giovanni, 2000: 239). Etap ten uznaje się za początki wyodrębnienia kultury hellenistycznej przez zainteresowanie naturą człowieka, wraz z jego wychowaniem i umiejętnościami. Sokrates dokonał rozwinięcia kultury humanistycznej, a swoją wiedzę przekazał uczniom, co zbudowało solidny konstrukt pedagogiki wychowania w kontekście dziedzictwa międzynarodowego. Warto jednak zwrócić uwagę na fakt, że nie zawsze był on postrzegany jako mistrz; Epikurejczycy początkowo oskarżali go o deprawowanie młodzieży oraz bezbożność (Frodeman, Briggle: 2016). Dopiero w latach 70. dorobek Sokratesa stał się przedmiotem badań interdyscyplinarnych w świecie nauki (Delikonstantinidou, 2020).

Jedną ze współczesnych teorii nauczania czerpiących inspirację z idei Sokratesa oraz indywidualizmu jest model progresywny edukacji wg D. Brandes i P. Ginnisa (Brandes, Ginnis, 1994: 47). Teoria ta w centrum uwagi stawia ucznia oraz koncentrowała się na nauce przez doświadczanie za pomocą stawianych pytań i popełnionych błędów. Otwarta dyskusja, kręgi, burze mózgów, współpraca i partnerstwo to fundamenty modelu progresywnego (Brandes, Ginnis, 1994). Istotną kwestią jest także obniżenie rangi autorytetu nauczyciela oraz zaakceptowanie prawa ucznia do błędów i niewiedzy. Twórcy tej teorii zaakcentowali dodatkowo znaczenie relacji i kontaktu we wzajemnej komunikacji, uwzględniając nawet wartość przywitania za pomocą uścisku (Brandes, Ginnis, 1994: 57). 
Rycina 1. Model progresywny w edukacji według D. Brandes i P. Ginnisa

Teoria progresywna Indywidualność
kształcenia

kształcenia

Prawo do błędów i pytań

Doświadczanie

Źródło: opracowanie własne na podstawie: Brandes, Ginnis (1994)

Model ten zyskuje na znaczeniu także w aspekcie powszechnej obecnie edukacji zdalnej, która $\mathrm{z}$ racji swej specyfiki utrzymuje sferę kontaktów w przestrzeni wirtualnej, a tym samym pozostawia komunikację na poziomie powierzchownym i biernym. Teoria progresywna stoi więc w opozycji do tradycyjnego modelu edukacji, opartego na zbiorowości i zasadach, przypominając o hellenistycznym wspieraniu poczucia autonomii oraz budowaniu relacji.

\section{Współczesna heurystyka w perspektywie podmiotowości}

Heurystyka (gr. heuresis - 'odnaleźć') jest dziedziną zapoczątkowaną przez Sokratesa, określaną jako metoda poszukująca, która pozwala odnajdywać, określić zależności oraz rozwiązywać problemy w sposób samodzielny (Wojnowski, 2002: 284). Metoda heurezy skupia się przede wszystkim na zadawaniu pytań zarówno przez uczniów, jak i przez nauczyciela (Ogłoza, 2000: 90). Prowadzi ona tym samym do rozumienia, które według czołowych greckich filozofów stanowi narzędzie na drodze odnalezienia prawdy (Koutsoyiannis, Mamassis, 2021). To właśnie pytania zadawane przez dydaktyka powinny zaktywizować ucznia do postawienia kolejnego pytania bądź też do szukania komplementarnej odpowiedzi.

Tak zwany dialog sokratejski, wpisujący się w koncepcję heurystyki, zwany też metodą sokratejską, stanowi rozmowę bez arbitra, opartą na prawach równorzędności nauczyciela z uczniem (Jodłowska, 2016). Proces ten pomaga również w odnajdywaniu indywidualnej ścieżki rozwoju przez kierowanie uwagi ucznia na własne potrzeby, intuicyjny wgląd do błędów oraz ustalenie priorytetów. Według R. Maliszewskiego, teorię Sokratesa uznaje się za formę dialogu edukacyjnego, gdzie metodą poszukiwań uczeń dochodzi do sedna problemu (Maliszewski, 2019: 100). Dla filozofa teoria ta stanowiła tym samym możliwość dokonania transferu poglądowości, otwarcia na nowe perspektywy poznania oraz zredukowania błędnego stanowiska (Maliszewski, 2019: 103).

W dialogu sokratejskim wyszczególniono dodatkowo dwie metody działania ze względu na dialektykę: metodę elenktyczną i metodę majeutyczną (Maliszewski, 2019: 104). Metoda elenktyczna, zwana także etapem negatywnym, polegała na przyjęciu przez 
nauczyciela perspektywy rozmówcy poprzez pozorne zaakceptowanie jego tezy w celu wywołania u niego własnych wniosków i obserwacji na drodze zadawania kolejnych pytań. Następowało wówczas stopniowe „zbijanie” rozmówcy z jego punktu widzenia, co miało prowadzić do „oczyszczenia” (Giovanni, 2000: 377). Celem tego podejścia było zmuszenie ucznia do myślenia oraz weryfikacji własnych poglądów i zasadności postawionych tez. Wymagało to jednocześnie umiejętności wychodzenia ponad „ego” i przyzwolenia na błąd.

Metoda majeutyczna, traktowana czasem jako kolejny etap po próbie elenktycznej (etap pozytywny), polegała na wydobyciu z podświadomości ucznia prawdziwej wiedzy, a tym samym na „narodzinach” nowego człowieka i dotarciu do prawdy (Krońska, 2001: 70). Sokrates nie podsuwał nigdy gotowych rozwiązań, był jedynie pomocnikiem na drodze do prawdziwego poznania.

Należy podkreślić, że twórca tej dialektyki stworzył owe metody dialogu w trosce o podmiotowość i prawdę, co stanowiło główny trzon jego idei. Kult podmiotowości był kontynuacją rozważań sokratejskich na temat duszy w myśl ideałów etycznych kalokagathii oraz areté. Celem Sokratesa nigdy nie było stworzenie narzędzia do ewaluacji i weryfikacji wiedzy, natomiast ukazanie przestrzeni do dialogu inicjującego samopoznanie.

Dialektyka Sokratesa we współczesnej heurystyce może być kluczem do przeformułowania warunków edukacji. Jego metoda pozwala utrzymywać ucznia w interakcji z jednoczesnym zachowaniem etyki, szacunku oraz prawa do autonomii. Tym samym stwarza przestrzeń do indywidualnych rozważań i wniosków u osoby nabywającej wiedzę. W sytuacji kryzysu gospodarczego dialog sokratejski wydaje się być realną metodą utrzymywania komunikacji w warunkach izolacji społecznej.

Nauka w systemie zdalnym, jak zaznacza Danuta Morańska, powinna opierać się na dialogicznej konfrontacji z innymi uczniami oraz na indywidualnym planowaniu edukacji w zakresie tempa, treści, następnie samokontroli oraz samooceny. Uczeń powinien mieć prawo do samodzielnej ewaluacji efektów swojej pracy oraz do monitorowania postępów (Morańska, 2017). Istotna jest także dbałość o standardy techniczne, takie jak posiadanie kamery internetowej czy też mikrofonu, aby zapobiec ewentualnemu poczuciu wykluczenia. Gwarancja dialogu w sytuacji nauczania zdalnego stanowi niezbędne ogniwo do rozwoju życia społecznego oraz podtrzymania relacji. Nie można jednak zapominać o dbałości w zakresie jakości merytorycznej i technicznej takiej metody komunikacji, w której centrum zainteresowania zawsze powinien stać uczeń, a nie założenia programowe. Edukacja zdalna wymaga więcej troski ze strony nauczyciela, kreatywności oraz panowania nad własnym ego, aby wzajemny kontakt stanowił przestrzeń do rozwoju, akceptacji i szacunku. Komunikacja zdalna tylko wtedy ma sens, jeżeli zapewnia warunki komfortu i interaktywności społeczno-edukacyjnej. W przeciwnym razie prowadzi do obciążenia, odtwórczości, co ciągnie za sobą ryzyko braku motywacji i poczucie wykluczenia.

Umiejętna postawa dialogiczna może zachęcać więc ucznia do wzięcia udziału w dyskusji edukacyjnej oraz skłaniać go do refleksji nawet w systemie edukacji zdalnej i w uwarunkowaniach technologicznych. Metoda sokratejska kształtuje także umiejętności retoryczne, logiczne czy dialektyczne równolegle ze zdolnością nieidentyfikowania się z ego. Następuje wówczas poszerzanie horyzontów i punktów widzenia, co przyspiesza proces edukacji. Efektem dodatkowym staje się wzrost świadomości ucznia. 


\section{Podsumowanie}

Niniejszy artykuł przedstawił ponadczasowe metody wraz z przynależnymi im wartościami, które mogą mieć wpływ na ustabilizowanie edukacji oraz poprawę jej kondycji. W myśl popularnego sofickiego aforyzmu - gnôthi sautón - 'poznaj samego siebie' - naczelną zasadą nauczania powinno być umożliwienie samopoznania jednostce (Krokiewicz, Domański, 2007). W kontekście powyższych analiz tylko w warunkach zachowania prawa do autonomii, doświadczania, kontaktu z innymi ludźmi i kulturą, człowiek posiada łatwość nabywania wiedzy. W perspektywie kryzysu gospodarczego oraz zdewaluowania pojęcia moralności istotne jest zwrócenie się pedagoga w stronę dialogu, empatii i poszanowania prawa do indywidualności. Równolegle niezbędnym czynnikiem staje się umożliwienie uczniom wymiany międzykulturowej i językowej wraz z pielęgnowaniem postaw patriotycznych. Stabilizowanie młodego pokolenia w obszarze moralności równolegle z uwrażliwianiem na sztukę stwarza przestrzeń do szacunku i elitarności. Ważnym aspektem jest także komunikacja, której istotnymi składnikami są zaakceptowanie prawa ucznia do błędu oraz stworzenie mu perspektyw do poszukiwań, eksperymentów i autorefleksji. Tym samym następuje zwrot do zasady partnerstwa i wzajemności w relacji, obniżający rangę autorytetu nauczyciela i skracający dystans. Inspiracje hellenistyczne w szkołach edukacji alternatywnej, eksperymentalnej i progresywnej poszerzają dodatkowo możliwości współczesnego nauczania.

Niniejsze opracowanie pomogło wskazać obszary do pracy nauczyciela w aspekcie możliwości i braków. Odpowiednia postawa dydaktyczna może zminimalizować skutki zmian i kryzysów poprzez pielęgnowanie wzajemnej komunikacji, wartości oraz dostrajanie do potrzeb jednostki. Wydaje się to możliwe mimo utrudnień w aspekcie edukacji zdalnej oraz przeniesienia relacji do sfery wirtualnej. Tylko wysoka jakość merytoryczna, zasoby empatii, szacunku i zrozumienia mają szansę złagodzić zagrożenia wynikające $\mathrm{z}$ transformacji gospodarczych. Obserwacje te prowadzą do konkluzji, iż dziedzictwo greckich mistrzów pozostawiło nauce ponadczasowe myśli i wzorce, do których warto wracać.

Literatura

References

Brandes, D., Ginnis, P.(1994). A Guide to Student - Centred Learning. Hemel Hampstead: Simon \& Schuster Education, 36-57.

Budzyński, M. (2021; 20 stycznia). Wychowanie do samowychowania i samoedukacji. Pozyskano z: https://ala.edu.pl/koncepcja

Chrzanowska, I., Szumski, G. (red.). (2019). Edukacja włączająca w przedszkolu i szkole. Warszawa: FRSE.

Czekańska-Mirek, B. (2016). Elementy coachingu jako narzędzie procesu nauczania i oceniania w dydaktyce języka obcego. Katowice: Wydawnictwo Uniwersytetu Śląskiego.

Danek, Z (2020). Lider o słabym głosie, czyli wizerunek własny Izokratesa. Meander, 75 (2020), 3-25.

Delikonstantinidou, A. (2020). Socrates Now or The Apology Project: From Greek Roots to Transnational Routes. Ex-centric Narratives: Journal of Anglophone Literature, Culture and Media, 4, 206-219.

Dembiński, B. (red.). (2000). W kręgu filozofii klasycznej. Katowice: Wydawnictwo Uniwersytetu Śląskiego. 
Frodeman, R., Briggle, A. (2016). Socrates tenured : the institutions of twenty-first-century philosophy. London: Rowman \& Littlefield International.

Jacko, J.F. (2017). Klasyczny ideał kształcenia a potrzeby społeczne. Kraków: Wydawnictwo Uniwersytetu Jagiellońskiego.

Jodłowska, B. (2016). Wokół początków pedagogiki. W trosce o powrót do Pedagogiki Sokratejskiej. Polska Myśl Pedagogiczna, 2, 83-99.

Gaj, B. (2020). Styl łacińskich traktatów Firmicusa Maternusa i Filastra z Brescii (IV w. p.n.e.). Stylistyka, $29,411-423$.

Giovanni, R. (2000). Historia filozofii starożytnej. Lublin: Katolicki Uniwersytet Lubelski.

Koutsoyiannis, D. Mamassis, N. (2021). From mythology to science: the development of scientific hydrological concepts in Greek antiquity and its relevance to modern hydrology. Hydrology and Earth System Science, 25. Pozyskano z: http://www.hess.copernicus.org

Krokiewicz, A., Domański, J. (2007). Gnothi seauton - Poznaj siebie!. Meander, 62(3-4), 197-210.

Krońska, I. (2001). Myśli i ludzie - Sokrates. Warszawa: Wiedza Powszechna.

Kwietniewska, M. (2020). Plato and Aristotle in the light of research on Indo-European culture. Kultura i Wartości, 29, 113-137.

Litak, S. (2010). Historia wychowania. Tom I. Kraków: WAM.

Łażewska, D. (2011). Filozofia dla pracujacych. Józefów: WSGE.

Maliszewski, R. (2019). Rola dialogu w procesie wychowawczym. Pedagogika Społeczna, 1(71), 100-104. doi: 10.35464/1642-672X.PS.2019.1.06

Marek, S., Szymańska-Wieczorek, A. (2011). Przyczyny i przewidywane skutki kryzysu finansowego XXI wieku. Studia i Prace Wydziału Nauk Ekonomicznych i Zarzadzania, 21, 228-234.

Morańska, D. (2017), Refleksyjne uczenie się w akademickiej edukacji zdalnej. Edukacja - Technika Informatyka, 1(19).

Ogłoza, E. (2000). Metody nauczania w kształceniu literackim. Katowice: Wydawnictwo Uniwersytetu Śląskiego.

Śmigaj, J. (2010). Rozmowy tuskulańskie - Cyceron. Tom V. Warszawa: Agora.

Szyrwińska-Hörig, A. (2021). Problem słabości woli w filozofii Leibniza w kontekście wczesno nowożytnych indeterministycznych teorii wolności. Studia $z$ Historii Filozofii, 1(12), 7-24.

Teodorovich, Z.B. (2021). O logosie w pismach Filona z Aleksandrii - ewolucja tematyki o logosie według doktryny metafizycznej Filona w starożytnej filozofii greckiej. Colloquium Journal, 1(88), 26-32.

Thagard, P. ( 2014). Kogniwistyka. W: Zalta, E.N. (red.). Cognitive Science. Stanford University. Pozyskano z: https://www.wikiwand.com/pl/Kognitywistyka\#/Przypisy

Wasilewski, M. (2017). Pedagogika grecka - od Protagorasa do Posejdoniosa. Łódź: Wydawnictwo Uniwersytetu Łódzkiego.

Wojnowski, J. (2002). Wielka encyklopedia. Tom 11. Warszawa: PWN.

Zalewska-Jura, H. (2021). Sekret Chloris, czyli o greckich antroponimach w Pieśniach Horacego. Między oryginałem a przekładem, 1(51), 125-138.

Zalta, E.N. (red.). (2017). The Stanford Encyclopedia of Philosophy (Summer 2016 Edition). The Metaphysics Research Lab. Pozyskano z: http://plato.stanford.edu/

Zarzycki, L.(2012). Teoretyczne podstawowe wychowania. Jelenia Góra: Karkonoska Szkoła Wyższa.

Dorota Okrasińska, absolwentka Wyższej Szkoły Kształcenia Zawodowego w Przemyślu, studiów podyplomowych - tutoring i coaching w edukacji, afiliacja Fundacji Gotowi na Zmiany. Ukończyła studia magisterskie na kierunku pedagogika, o specjalności zintegrowana edukacja wczesnoszkolna oraz studia podyplomowe zarządzanie oświatą - lider i manager (Wyższa Szkoła Biznesu i Przedsiębiorczości w Ostrowcu Świętokrzyskim, oddział KIRE w Krakowie). Jej zainteresowania badawcze i naukowe dotyczą pedagogiki, zarządzania, przedsiębiorczości i filozofii.

Dorota Okrasińska, graduate of postgraduate studies - Tutoring and coaching in education - at the Higher School of Professional Education in Przemyśl; affiliated with the Ready for Changes 
Foundation. She holds an MA degree in Pedagogy, specialising in Integrated Early School Education and has completed postgraduate studies in Educational Management - Leader and manager (University of Business and Entrepreneurship in Ostrowiec Świętokrzyski, KIRE branch in Krakow). Her research and scientific interests concern pedagogy, management, entrepreneurship and philosophy.

ORCID: https://orcid.org/0000-0001-8629-7922

\section{Adres/Address:}

Fundacja Gotowi na Zmiany

ul. Siewna 21c lok. 30

32-223 Kraków, Poland

e-mail: dorota.okrasinska@onet.eu 